\title{
Ragam Konjungsi pada Rubrik Nusantara Surat Kabar Digital Mediaindonesia.com Edisi Mei 2021 dan Pemanfaatannya sebagai Bahan Ajar Teks Berita di Kelas VIII SMP
}

\author{
Rian Yoana \\ (corresponding author) \\ Program Studi Pendidikan Bahasa dan Sastra Indonesia \\ Universitas Singaperbangsa Karawang \\ Email: 1710631080133@student.unsika.ac.id \\ Oding Supriadi \\ Program Studi Pendidikan Bahasa dan Sastra Indonesia \\ Universitas Singaperbangsa Karawang \\ Email: Oding.supriadi@fkip.unsika.ac.id

\section{Sahlan Mujtaba} \\ Program Studi Pendidikan Bahasa dan Sastra Indonesia \\ Universitas Singaperbangsa Karawang \\ Email: sahlan.mujtaba@fkip.unsika.ac.id
}

APA Citation: Yoana, R., Supriadi, O., \& Mujtaba, S. (2021). Ragam Konjungsi pada Rubrik Nusantara Surat Kabar Digital Mediaindonesia.com Edisi Mei 2021 dan Pemanfaatannya sebagai Bahan Ajar Teks Berita di Kelas VIII SMP. Silampari Bisa: Jurnal Penelitian Pendidikan Bahasa Indonesia, Daerah, dan Asing, 4(2), 398-413. https://doi.org/10.31540/silamparibisa.v4i2.1379

\begin{abstract}
Abstrak
Tujuan dari penelitian ini adalah mengetahui ragam jenis konjungsi pada rubrik nusantara surat kabar digital Mediaindonesia.com edisi Mei 2021 dan mendeskripsikan pemanfaatan ragam jenis konjungsi pada rubrik nusantara surat kabar digital Mediaindonesia.com edisi Mei 2021 sebagai bahan ajar teks berita di kelas VIII SMP. Penelitian ini termasuk jenis penelitian kualitatif yang menggunakan metode deskriptif kualitatif. Subjek penelitian ini adalah rubrik nusantara surat kabar digital Mediaindonesia.com edisi Mei 2021. Objek penelitian ini adalah ragam jenis konjungsi yang terdapat pada rubrik nusantara surat kabar digital Mediaindonesia.com edisi Mei 2021. Teknik pengumpulan data penelitian ini adalah observasi dan dokumentasi. Teknik analisis data penelitian ini adalah reduksi data, penyajian data, dan penarikan kesimpulan. Berdasarkan hasil penelitian pada rubrik nusantara surat kabar digital Mediaindonesia.com edisi Mei 2021 ditemukan 88 data ragam jenis konjungsi yang terdiri dari 39 data konjungsi koordinatif dan 49 data konjungsi subordianatif. Hasil penelitian ragam jenis konjungsi pada rubrik nusantara surat kabar digital Mediaindonesia.com edisi Mei 2021 selanjutnya dimanfaatkan sebagai bahan ajar teks berita di kelas VIII SMP.
\end{abstract}

Kata kunci: konjungsi, rubrik, surat kabar digital, bahan ajar teks berita 
Rian Yoana, Oding Supriadi, Sahlan Mujtaba

Ragam Konjungsi pada Rubrik Nusantara Surat Kabar Digital Mediaindonesia.com Edisi Mei 2021 dan Pemanfaatannya sebagai Bahan Ajar Teks Berita di Kelas VIII SMP

\title{
Various Type of Conjunction in the Archipelago Rubric Digital Newspaper Mediaindonesia.com May 2021 Edition and Its Utilization as Teaching Material for News Texts in Class VIII SMP
}

\begin{abstract}
The purpose of this research was to find out various type of conjunction in the archipelago rubric digital newspaper Mediaindonesia.com May 2021 edition and to describe the use of various type of conjunction in the archipelago rubric digital newspaper Mediaindonesia.com May 2021 edition as teaching material for news texts in class VIII SMP. This research is a type of qualitative research which uses a qualitative descriptive method. The subjects in this study is the archipelago rubric digital newspaper Mediaindonesia.com May 2021 edition. The objects in the study is various type of conjunction which is in the archipelago rubric digital newspaper Mediaindonesia.com May 2021 edition. The data collection techniques of this research are observation and documentation. Data analysis techniques in this study are data reduction, data presentation, and drawing conclusions. Based on research results in the archipelago rubric digital newspaper Mediaindonesia.com May 2021 edition it was found 88 various type of conjunction which consists of 39 coordinating conjunction and 49 subordinating conjunction. Research result various type of conjunction in the archipelago rubric digital newspaper Mediaindonesia.com May 2021 edition the next is used as teaching material for news texts in class VIII SMP.
\end{abstract}

Keywords: conjunction, rubric, digital newspaper, news text teaching materials

\section{A. Pendahuluan}

Pesatnya kemajuan teknologi membawa banyak kemudahan bagi masyarakat. Termasuk kemajuan internet yang memudahkan setiap individu dalam mendapatkan informasi melalui surat kabar digital. Melalui surat kabar digital setiap individu dapat dengan mudah mendapatkan informasi apapun, baik itu untuk dirinya sendiri maupun untuk dibagikan kepada orang lain Sa-Ah (2019). Akan tetapi, kemudahan setiap individu dalam mendapatkan informasi ternyata menimbulkan dampak, khususnya bagi masyarakat.

Kemudahan setiap individu dalam mendapatkan informasi menyebabkan banyak berita yang tersebar di lingkungan masyarakat sehingga masyarakat sulit untuk memeriksa kebenaran berita. Berdasarkan survei yang dilakukan oleh Mastel (2019) ada sebanyak 58\% responden yang menyatakan alasan tidak memeriksa kebenaran berita karena mengira bahwa berita yang didapatkan telah melewati proses pemeriksaan. Padahal tidak semua berita pada surat kabar digital melewati proses pemeriksaan sehingga tidak semua berita pada surat kabar digital dijamin mengandung informasi yang benar. Selain itu, tidak semua berita pada surat kabar digital menyampaikan informasi secara utuh.

Demi membuat berita yang singkat kerap ada informasi yang dikurangi, dihilangkan, atau bahkan dimanipulasi. Padahal informasi dalam berita tidak perlu dikurangi, dihilangkan, atau bahkan dimanipulasi, tetapi dapat dihubungkan menggunakan konjungsi. Menurut Kridalaksana (2008:102) konjungsi adalah kategori yang berfungsi untuk meluaskan satuan-satuan yang lain dalam konstruksi hipotaktis dan selalu menghubungkan dua satuan lain atau lebih dalam konstruksi. Konjungsi menghubungkan bagian-bagian ujaran yang setataran maupun yang tidak setataran. 
Menurut Rohmadi, dkk. (2010:195) konjungsi atau kata sambung atau conjunctio ialah kata yang menghubungkan kata dengan kata lain, menghubungkan bagian kalimat dengan bagian kalimat yang lain atau menghubungkan kalimat dengan kalimat yang lain. Menurut Alwi, dkk. (2010:301) konjungsi atau konjungtor, yang juga dinamakan kata sambung, adalah kata tugas yang menghubungkan dua satuan bahasa yang sederajat: kata dengan kata, frasa dengan frasa, atau klausa dengan klausa. Menurut Chaer (2015:81) konjungsi adalah kategori yang menghubungkan kata dengan kata, klausa dengan klausa, atau kalimat dengan kalimat; bisa juga antara paragraf dengan paragraf. Dengan adanya konjungsi dalam berita, maka informasi dalam berita, baik itu informasi yang berbentuk kata, frasa, klausa, kalimat, maupun paragraf dapat terhubung.

Maka dari itu, konjungsi dalam berita tidak boleh diabaikan begitu saja karena apabila diabaikan akan ada beberapa masalah yang muncul. Pertama, jika konjungsi tidak ada dalam berita, maka akan menyebabkan informasi dalam berita menjadi tidak terhubung sehingga setiap individu yang mendapatkan berita akan kesulitan memahami informasi dalam berita. Mereka hanya akan cenderung untuk membaca judul berita tanpa memahami informasi dalam berita sehingga akhirnya mereka tidak mengetahui kebenaran berita yang didapatkan. Oleh karena itu, konjungsi sangat dibutuhkan dalam berita pada surat kabar digital, tetapi bukan berarti konjungsi hanya harus sekadar ada.

Kedua, jika konjungsi hanya sekadar ada dalam berita, maka akan menyebabkan informasi dalam berita tidak tersampaikan secara utuh sehingga tujuan dari berita tidak dapat diketahui dengan jelas. Setiap individu yang mendapatkan berita akan mengalami kesimpangsiuran dalam memahami tujuan dari berita yang didapatkan sehingga akhirnya mereka hanya akan melakukan praduga terhadap berita yang didapatkan. Oleh karena itu, jenis konjungsi dalam berita pada surat kabar digital tidak boleh terbatas. Idealnya, jenis konjungsi dalam berita pada surat kabar digital seharusnya beragam supaya informasi dalam berita dapat terhubung dan tersampaikan secara utuh sehingga tujuan dari berita dapat diketahui dengan jelas tanpa ada informasi yang dikurangi, dihilangkan, atau bahkan dimanipulasi.

Demi mengetahui ragam jenis konjungsi dalam berita pada surat kabar digital, maka penulis melakukan penelitian. Penulis melakukan penelitian mengenai ragam jenis konjungsi dalam berita pada surat kabar digital Mediaindonesia.com. Mediaindonesia.com merupakan surat kabar digital yang berbentuk portal berita. Surat kabar digital Mediaindonesia.com daya edarnya berskala nasional.

Surat kabar digital Mediaindonesia.com memiliki beberapa rubrik, salah satunya rubrik nusantara. Rubrik nusantara merupakan rubrik yang berisi beritaberita dengan informasi seputar kejadian-kejadian dari seluruh wilayah Indonesia. Salah satunya pada bulan Mei 2021 terdapat berita yang sedang hangat di lingkungan masyarakat, yaitu berita dengan topik seputar larangan dan penyekatan mudik. Oleh karena itu, ragam jenis konjungsi pada rubrik nusantara surat kabar digital Mediaindonesia.com edisi Mei 2021 diteliti.

Ragam jenis konjungsi juga kerap dipelajari oleh peserta didik pada Mata Pelajaran Bahasa Indonesia. Pada Mata Pelajaran Bahasa Indonesia kurikulum 2013 kelas VIII SMP, terdapat tema pembelajaran teks berita. Pada tema pembelajaran teks berita ada beberapa jenis konjungsi yang kerap dipelajari oleh

Silampari Bisa: Jurnal Penelitian Pendidikan Bahasa Indonesia, Daerah, dan Asing Vol. 4, No. 2, 2021 
peserta didik melalui bahan ajar Kemdikbud edisi revisi 2017. Dengan demikian, maka hasil penelitian ragam jenis konjungsi pada rubrik nusantara surat kabar digital Mediaindonesia.com edisi Mei 2021 selanjutnya dimanfaatkan sebagai bahan ajar teks berita di kelas VIII SMP.

Penelitian mengenai ragam jenis konjungsi pernah dilakukan oleh Ratnaningsih, dkk. (2021) dengan judul "Analisis Konjungtor dalam Kolom Editorial Surat Kabar Lampung Post'. Perbedaan antara penelitian Ratnaningsih, dkk. dengan penelitian penulis terletak pada subjek penelitian. Subjek penelitian Ratnaningsih, dkk adalah kolom berita surat kabar Lampung Post, sedangkan subjek penelitian penulis adalah rubrik nusantara surat kabar digital Mediaindonesia.com edisi Mei 2021. Perbedaan lain antara penelitian Ratnaningsih, dkk dengan penelitian penulis, yaitu hasil penelitian Ratnanigsih, dkk. tidak dimanfaatkan sebagai bahan ajar, sedangkan hasil penelitian penulis selanjutnya dimanfaatkan sebagai bahan ajar teks berita di kelas VIII SMP.

Penelitian mengenai ragam jenis konjungsi yang kedua pernah dilakukan oleh Rekso, dkk. (2021) dengan judul "Ragam Konjungsi dalam Artikel Pendidikan Harian Suara Merdeka dan Relevansinya dengan Pembelajaran Teks Eksposisi”. Perbedaan antara penelitian Rekso dkk. dengan penelitian penulis terletak pada subjek penelitian. Subjek penelitian Rekso dkk adalah artikel pendidikan harian Suara Merdeka, sedangkan subjek penelitian penulis adalah rubrik nusantara surat kabar digital Mediaindonesia.com edisi Mei 2021. Perbedaan lain antara penelitian Rekso, dkk dengan penelitian penulis, yaitu hasil penelitian Rekso dkk. selanjutnya direlevansikan terhadap pembelajaran teks eksposisi, sedangkan hasil penelitian penulis selanjutnya dimanfaatkan sebagai bahan ajar teks berita di kelas VIII SMP.

Penelitian mengenai ragam jenis konjungsi yang ketiga pernah dilakukan oleh Sari, dkk. (2020) dengan judul "Konjungsi pada Harian Rakyat Bengkulu". Perbedaan antara penelitian Sari, dkk. dengan penelitian penulis terletak pada subjek penelitian. Subjek penelitian Sari, dkk. adalah Harian Rakyat Bengkulu, sedangkan subjek penelitian penulis adalah rubrik nusantara surat kabar digital Mediaindonesia.com edisi Mei 2021. Perbedaan lain antara penelitian Sari, dkk. dengan penelitian penulis, yaitu hasil penelitian Sari, dkk. tidak dimanfaatkan sebagai bahan ajar, sedangkan hasil penelitian penulis selanjutnya dimanfaatkan sebagai bahan ajar teks berita di kelas VIII SMP.

Penelitian mengenai ragam jenis konjungsi yang keempat pernah dilakukan oleh Siagian, dkk. (2020) dengan judul "Analisis Penggunaan Konjungsi dalam Kumpulan Artikel pada Rubrik Politik Hukum Koran Kompas". Perbedaan antara penelitian Siagian, dkk. dengan penelitian penulis terletak pada subjek penelitian. Subjek penelitian Siagian, dkk. adalah kumpulan artikel pada rubrik politik hukum koran Kompas, sedangkan subjek penelitian penulis adalah rubrik nusantara surat kabar digital Mediaindonesia.com edisi Mei 2021. Perbedaan lain antara penelitian Siagian, dkk. dengan penelitian penulis, yaitu hasil penelitian Siagian, dkk. tidak dimanfaatkan sebagai bahan ajar, sedangkan hasil penelitian penulis selanjutnya dimanfaatkan sebagai bahan ajar teks berita di kelas VIII SMP.

Penelitian mengenai ragam jenis konjungsi yang kelima pernah dilakukan oleh Tara \& WM (2020) dengan judul "Penggunaan Konjungsi Koordinatif dalam Berita Editorial Surat Kabar Tribun Jambi Bulan Januari 2019". Perbedaan antara penelitian Tara dan WM dengan penelitian penulis terletak pada subjek penelitian. Subjek penelitian Tara dn WM adalah berita editorial surat kabar Tribun Jambi, 
sedangkan subjek penelitian penulis adalah rubrik nusantara surat kabar digital Mediaindonesia.com edisi Mei 2021. Perbedaan lain antara penelitian Tara dan WM dengan penelitian penulis, yaitu hasil penelitian Tara dan WM tidak dimanfaatkan sebagai bahan ajar, sedangkan hasil penelitian penulis selanjutnya dimanfaatkan sebagai bahan ajar teks berita di kelas VIII SMP.

Penelitian mengenai ragam jenis konjungsi yang keenam pernah dilakukan oleh Cenderamata (2018) dengan judul "Penggunaan Konjungsi dalam Surat Kabar Republika Online Edisi Maret-Mei 2018". Perbedaan antara penelitian Cenderamata dengan penelitian penulis terletak pada subjek penelitian. Subjek penelitian Cenderamata adalah surat kabar Republika Online edisi Maret - Mei 2018, sedangkan subjek penelitian penulis adalah rubrik nusantara surat kabar digital Mediaindonesia.com edisi Mei 2021. Perbedaan lain antara penelitian Cenderamata dengan penelitian penulis, yaitu hasil penelitian Cenderamata tidak dimanfaatkan sebagai bahan ajar, sedangkan hasil penelitian penulis selanjutnya dimanfaatkan sebagai bahan ajar teks berita di kelas VIII SMP.

Penelitian mengenai ragam jenis konjungsi yang ketujuh pernah dilakukan oleh Jufri (2018) dengan judul "Analisis Penggunaan Konjungsi Koordinatif dan Subordinatif pada Rubrik Nasional Surat Kabar Harian Fajar Edisi Desember 2017". Perbedaan antara penelitian Jufri dengan penelitian penulis terletak pada subjek penelitian. Subjek penelitian Jufri adalah rubrik nasional pada surat kabar Harian Fajar edisi Desember 2017, sedangkan subjek penelitian penulis adalah rubrik nusantara surat kabar digital Mediaindonesia.com edisi Mei 2021. Perbedaan lain antara penelitian Jufri dengan penelitian penulis, yaitu hasil penelitian Jufri tidak dimanfaatkan sebagai bahan ajar, sedangkan hasil penelitian penulis selanjutnya dimanfaatkan sebagai bahan ajar teks berita di kelas VIII SMP.

Penelitian mengenai ragam jenis konjungsi yang terakhir pernah dilakukan oleh Melia (2018) dengan judul "Analisis Penggunaan Konjungsi Bahasa Indonesia pada Editorial Surat Kabar Tribun Pontianak". Perbedaan antara penelitian Melia dengan penelitian penulis terletak pada subjek penelitian. Subjek penelitian Melia adalah editorial surat kabar Tribun Pontianak edisi Desember 2016, sedangkan subjek penelitian penulis adalah rubrik nusantara surat kabar digital Mediaindonesia.com edisi Mei 2021. Perbedaan lain antara penelitian Melia dengan penelitian penulis, yaitu hasil penelitian Melia tidak dimanfaatkan sebagai bahan ajar, sedangkan hasil penelitian penulis selanjutnya dimanfaatkan sebagai bahan ajar teks berita di kelas VIII SMP.

Berdasarkan latar belakang di atas, penulis melakukan penelitian dengan judul "Ragam Jenis Konjungsi pada Rubrik Nusantara Surat Kabar Digital Mediaindonesia.com Edisi Mei 2021 dan Pemanfaatannya sebagai Bahan Ajar Teks Berita di Kelas VIII SMP". Tujuan dari penelitian adalah mengetahui ragam jenis konjungsi pada rubrik nusantara surat kabar digital Mediaindonesia.com edisi Mei 2021 dan mendeskripsikan pemanfaatan ragam jenis konjungsi pada rubrik nusantara surat kabar digital Mediaindonesia.com edisi Mei 2021 sebagai bahan ajar teks berita di kelas VIII SMP. 
Rian Yoana, Oding Supriadi, Sahlan Mujtaba

Ragam Konjungsi pada Rubrik Nusantara Surat Kabar Digital Mediaindonesia.com Edisi Mei 2021 dan Pemanfaatannya sebagai Bahan Ajar Teks Berita di Kelas VIII SMP

\section{B. Metode Penelitian}

Penelitian ini termasuk jenis penelitian kualitatif yang menggunakan metode deskriptif kualitatif. Menurut Moleong (2018:11) dalam penelitian deskriptif data yang dikumpulkan adalah data berupa kata-kata, gambar, dan bukan angka-angka. Berdasarkan pernyataan tersebut, maka pada penelitian ini penulis mengumpulkan data kalimat yang mengandung ragam jenis konjungsi dari sumber data. Sumber data penelitian ini adalah berita pada rubrik nusantara surat kabar digital Mediaindonesia.com edisi Mei 2021.

Objek penelitian ini adalah ragam jenis konjungsi yang terdapat pada rubrik nusantara surat kabar digital Mediaindonesia.com edisi Mei 2021. Subjek penelitian ini adalah rubrik nusantara surat kabar digital Mediaindonesia.com edisi Mei 2021. Pada rubrik nusantara surat kabar digital Mediaindonesia.com edisi Mei 2021 ada sepuluh berita dengan topik seputar larangan dan penyekatan mudik. Dokumen sepuluh berita pada rubrik nusantara surat kabar digital Mediaindonesia.com edisi Mei 2021 tersebut kemudian dikumpulkan dengan menggunakan teknik pengumpulan data dokumentasi, sedangkan teknik pengumpulan data observasi digunakan untuk mengetahui gambaran umum dari surat kabar digital Mediaindonesia.com.

Pada penelitian ini instrumen penelitiannya adalah penulis itu sendiri. Menurut Sugiyono (2016:305) dalam penelitian kualitatif yang menjadi instumen atau alat penelitian adalah peneliti itu sendiri. Penulis sebagai instrumen pada penelitian ini juga menggunakan pedoman analisis penelitian. Pedoman analisis penelitian yang digunakan penulis adalah pedoman analisis penelitian ragam jenis konjungsi. Pedoman analisis penelitian itu disusun dalam bentuk tabel yang terdiri dari aspek yang diteliti dan indikator analisis penelitian.

Analisis data penelitian ini dilakukan menggunakan teknik analisis data, yaitu reduksi data, penyajian data, dan penarikan kesimpulan. Pada aktivitas reduksi data kalimat yang mengandung ragam jenis konjungsi dalam dokumen berita pada rubrik nusantara surat kabar digital Mediaindonesia.com edisi Mei 2021 ditandai menggunakan kode data berdasarkan urutan kalimat dan edisi terbitnya. Pada aktivitas penyajian data kalimat yang mengandung ragam jenis konjungsi yang telah ditandai menggunakan kode data selanjutnya dideskripsikan untuk kemudian dianalisis jenis konjungsinya. Pada aktivitas penarikan kesimpulan ragam jenis konjungsi pada rubrik nusantara surat kabar digital Mediaindonesia.com edisi Mei 2021 yang telah dianalisis selanjutnya disimpulkan secara deskriptif dalam bentuk paparan sebagai hasil penelitian. Hasil penelitian ragam jenis konjungsi pada rubrik nusantara surat kabar digital Mediaindonesia.com edisi Mei 2021 selanjutnya dimanfaatkan sebagai bahan ajar teks berita di kelas VIII SMP.

\section{Hasil Penelitian dan Pembahasan \\ 1. Hasil Penelitian}

Pada rubrik nusantara surat kabar digital Mediaindonesia.com edisi Mei 2021 ada sepuluh berita dengan topik seputar larangan dan penyekatan mudik. Berdasarkan hasil penelitian pada rubrik nusantara surat kabar digital Mediaindonesia.com edisi Mei 2021 ditemukan 65 data kalimat yang mengandung 88 data ragam jenis konjungsi yang terdiri dari 39 data konjungsi koordinatif dan 49 data konjungsi subordinatif. Konjungsi koordinatif yang ditemukan 39 data terdiri 
dari 15 data konjungsi penjumlahan, 7 data konjungsi pemilihan, 2 data konjungsi pertentangan, 1 data konjungsi pembetulan, 5 data konjungsi penegasan, 1 data konjungsi pembatasan, 1 data konjungsi pengurutan, 2 data konjungsi penyamaan, 2 data konjungsi penjelasan, dan 3 data konjungsi penyimpulan. Konjungsi subordinatif yang ditemukan 49 data terdiri dari 14 data konjungsi penyebaban, 2 data konjungsi persyaratan, 23 data konjungsi tujuan, 7 data konjungsi kesewaktuan, 2 data konjungsi pengakibatan, dan 1 data konjungsi perbandingan.

\section{Pembahasan}

a. Ragam Jenis Konjungsi pada Rubrik Nusantara Surat Kabar Digital Mediaindonesia.com Edisi Mei 2021

Pada rubrik nusantara surat kabar digital Mediaindonesia.com edisi Mei 2021 ada sepuluh berita dengan topik seputar larangan dan penyekatan mudik. Pada sepuluh berita rubrik nusantara surat kabar digital Mediaindonesia.com edisi Mei 2021 ditemukan kalimat yang mengandung ragam jenis konjungsi. Ragam jenis konjungsi dibedakan berdasarkan kedudukan konstituen yang dihubungkan. Menurut Chaer (2015:82) ditinjau dari kedudukan konstituen yang dihubungkan dibedakan adanya konjungsi koodinatif dan subordinatif.

Konjungsi koordinatif dibedakan atas konjungsi yang menghubungkan menyatakan penjumlahan, pemilihan, pertentangan, pembetulan, penegasan, pembatasan, pengurutan, penyamaan, penjelasan, dan penyimpulan. Konjungsi subordinatif dibedakan atas konjungsi yang menghubungkan menyatakan penyebaban, persyaratan, tujuan, penyungguhan, kesewaktuan, pengakibatan, dan perbandingan. Berdasarkan hasil penelitian pada rubrik nusantara surat kabar digital Mediaindonesia.com edisi Mei 2021 ditemukan 65 data kalimat yang mengandung 88 data ragam jenis konjungsi yang terdiri dari 39 data konjungsi koordinatif dan 49 data konjungsi subordinatif. Berikut adalah data konjungsi koordinatif dan konjungsi subordinatif yang ditemukan pada rubrik nusantara surat kabar digital Mediaindonesia.com edisi Mei 2021.

\section{1) Konjungsi Koordinatif}

Konjungsi koordinatif yang ditemukan 39 data pada rubrik nusantara surat kabar digital Mediaindonesia.com edisi Mei 2021 terdiri dari 15 data konjungsi penjumlahan, 7 data konjungsi pemilihan, 2 data konjungsi pertentangan, 1 data konjungsi pembetulan, 5 data konjungsi penegasan, 1 data konjungsi pembatasan, 1 data konjungsi pengurutan, 2 data konjungsi penyamaan, 2 data konjungsi penjelasan, dan 3 data konjungsi penyimpulan. Berikut adalah data konjungsi koordinatif pada rubrik nusantara surat kabar digital Mediaindonesia.com edisi Mei 2021.

\section{a) Konjungsi Penjumlahan}

Pada rubrik nusantara surat kabar digital Mediaindonesia.com edisi Mei 2021 ditemukan 15 data konjungsi penjumlahan dari kata dan. Berikut salah satu data yang menunjukan konjungsi penjumlahan.

Menurut Iwan, itu karena tidak ada surat pengantar dari RT, RW, dan desa. (D44/8/Mei/21) 
Kata dan pada data (44) merupakan konjungsi penjumlahan yang menghubungkan antarkata dengan menjumlahkan beberapa pihak, seperti RW dan desa yang keduanya merupakan kata berkategori nomina.

b) Konjungsi Pemilihan

Pada rubrik nusantara surat kabar digital Mediaindonesia.com edisi Mei 2021 ditemukan 7 data konjungsi pemilihan dari kata atau. Berikut salah satu data yang menunjukan konjungsi pemilihan.

Pengecualian pelaku perjalanan bagi pegawai ASN, BUMN, BUMD harus menunjukkan surat izin perjalanan tertulis atau Surat Izin Keluar/Masuk (SIKM) yang dikeluarkan oleh atasan setingkat Pejabat Eselon II begitu juga bagi pekerja swasta, sektoral informal dan masyarakat umum juga diatur secara detail dalam Surat Ederan tersebut. (D6/3/Mei/21)

Kata atau pada data (6) merupakan konjungsi pemilihan yang menghubungkan antarkata dengan memilih salah satu antara menunjukan surat izin perjalanan tertulis atau Surat Izin Keluar/Masuk (SIKM) yang keduanya merupakan kata berkategori nomina.

c) Konjungsi Pertentangan

Pada rubrik nusantara surat kabar digital Mediaindonesia.com edisi Mei 2021 ditemukan 2 data konjungsi pertentangan dari kata namun dan sedangkan. Berikut data yang menunjukan konjungsi pertentangan.

...ada keluarga yang sakit. Namun, setelah sampai di pos penyekatan Gentong, Tasikmalaya, Jawa Barat, mobilnya harus diputarbalikkan ke tujuan semula. (D43/8/Mei/21)

Menurut data yang didapatkan di lapangan, 14 kendaraan roda empat diminta putar balik dikarenakan tidak bisa menyertakan dokumen yang wajib dibawa, sedangkan sebanyak 476 kendaran diperiksa oleh petugas. (D80/12/Mei/21)

Kata namun pada data (43) merupakan konjungsi pertentangan yang menghubungkan antarkalimat dengan mempertentangkan ada keluarga yang sakit pada kalimat pertama. Kata sedangkan pada data (80) merupakan konjungsi pertentangan yang menghubungkan antarklausa dengan mempertentangkan 14 kendaraan roda empat yang diminta putar balik pada klausa pertama.

d) Konjungsi Pembetulan

Pada rubrik nusantara surat kabar digital Mediaindonesia.com edisi Mei 2021 ditemukan 1 data konjungsi pembetulan dari kata hanya. Berikut data yang menunjukan konjungsi pembetulan.

Namun sejauh ini, SGM masih diizinkan buka oleh Satgas Covid-19 Kota, dan hanya dilakukan tes swab antigen massal. (D76/11/Mei/21)

Kata hanya pada data (76) merupakan konjungsi pembetulan yang menghubungkan antarklausa dengan membetulkan keterangan SGM yang masih diizinkan buka oleh Satgas Covid-19 Kota pada klausa pertama. 


\title{
e) Konjungsi Penegasan
}

Pada rubrik nusantara surat kabar digital Mediaindonesia.com edisi Mei 2021 ditemukan 5 data konjungsi penegasan dari kata hanya dan apalagi. Berikut beberapa data yang menunjukan konjungsi penegasan.

\begin{abstract}
"Lakukan pengetatan seluruh jalur yang dimungkinkan akan dilalui kendaraan pemudik, tidak hanya jalan utama terapi juga jalan tikus, jalan jangkrik atau ruas manapun," ujar Ganjar Pranowo. (D15/5/Mei/21)

Anne menjelaskan, instruksi yang dituangkan dalam surat edaran bernomor 2443.1/1128/BKSDM itu tentang pembatasan pepergian ke luar daerah berupa cuti apalagi mudik untuk ASN telah disosialisasikan seluruh perangkat kerja. (D29/6/Mei/21)
\end{abstract}

Kata hanya pada data (15) merupakan konjungsi penegasan yang menghubungkan antarklausa dengan menegaskan bahwa pengetatan seluruh jalur yang dimungkinkan akan dilalui kendaraan pemudik pada klausa pertama tidak hanya di jalan utama pada klausa kedua. Kata apalagi pada data (29) merupakan konjungsi penegasan yang menghubungkan antarklausa dengan menegaskan instruksi yang dituangkan dalam surat edaran bernomor 2443.1/1128/BKSDM pada klausa pertama.

\section{f) Konjungsi Pembatasan}

Pada rubrik nusantara surat kabar digital Mediaindonesia.com edisi Mei 2021 ditemukan 1 data konjungsi pembatasan dari kata hanya. Berikut data yang menunjukan konjungsi pembatasan.

"Di gerbang Tol Cikampek Utama hanya 8.732 kendaraan, situasi normal jumlahnya 19.338 kendaraan. Adanya penyekatan turun 53 persen," ujarnya. (D39/7/Mei/21)

Kata hanya pada data (39) merupakan konjungsi pembatasan yang menghubungkan antarklausa dengan membatasi keterangan di gerbang Tol Cikampek Utama pada klausa pertama hanya terdapat 8.732 kendaraan pada klausa kedua.

g) Konjungsi Pengurutan

Pada rubrik nusantara surat kabar digital Mediaindonesia.com edisi Mei 2021 ditemukan 1 data konjungsi pengurutan dari kata kemudian. Berikut data yang menunjukan konjungsi pengurutan.

Beruntung kesigapan Satgas Jogo Tonggo, membuat pemudik yang sudah masuk di perkampungan, dapat dibawa masuk menjalani tes swab, yang kemudian diketahui ada tiga dengan positif terpapar. (D72/11/Mei/21)

Kata kemudian pada data (72) merupakan konjungsi pengurutan yang menghubungkan antarklausa dengan mengurutkan beberapa kejadian yang dialami oleh para pemudik yang sudah masuk perkampungan pada klausa kedua. 
h) Konjungsi Penyamaan

Pada rubrik nusantara surat kabar digital Mediaindonesia.com edisi Mei 2021 ditemukan 2 data konjungsi penyamaan dari kata yakni. Berikut salah satu data yang menunjukan konjungsi penyamaan.

Hasilnya satu terpapar, yakni seorang petugas cleaning service, yang langsung dilarikan ke Asrama Haji. (D77/11/Mei/21)

Kata yakni pada data (77) merupakan konjungsi penyamaan yang menghubungkan antarklausa dengan menyamakan satu terpapar dengan seorang petugas cleaning service.

i) Konjungsi Penjelasan

Pada rubrik nusantara surat kabar digital Mediaindonesia.com edisi Mei 2021 ditemukan 2 data konjungsi penjelasan dari kata bahwa. Berikut salah satu data yang menunjukan konjungsi penjelasan.

Rama pun mengklaim bahwa saat ini tak lagi pemudik yang bisa lolos penyekatan. (D55/9/Mei/21)

Kata bahwa pada data (55) merupakan konjungsi penjelasan yang menghubungkan antarklausa dengan menjelaskan tak ada lagi pemudik yang bisa lolos penyekatan pada klausa kedua merupakan klaim dari Rama sebagai subjek pada klausa pertama.

j) Konjungsi Penyimpulan

Pada rubrik nusantara surat kabar digital Mediaindonesia.com edisi Mei 2021 ditemukan 3 data konjungsi penyimpulan dari kata jadi. Berikut salah satu data yang menunjukan konjungsi penyimpulan.

"...ini masih di suasana pandemi Covid-19. Jadi, kami seluruh pegawai pemkab tidak boleh mudik dan cuti dulu," kata Anne Ratna Mustika. (D25/6/Mei/21)

Kata jadi pada data (25) merupakan konjungsi penyimpulan yang menghubungkan antarkalimat dengan menyimpulkan masih di suasana pandemi Covid-19 pada kalimat pertama.

2) Konjungsi Koordinatif

Konjungsi subordinatif yang ditemukan 49 data pada rubrik nusantara surat kabar digital Mediaindonesia.com edisi Mei 2021 terdiri dari 14 data konjungsi penyebaban, 2 data konjungsi persyaratan, 23 data konjungsi tujuan, 7 data konjungsi kesewaktuan, 2 data konjungsi pengakibatan, dan 1 data konjungsi perbandingan. Berikut adalah data konjungsi subordinatif pada rubrik nusantara surat kabar digital Mediaindonesia.com edisi Mei 2021.

a) Konjungsi Penyebaban

Pada rubrik nusantara surat kabar digital Mediaindonesia.com edisi Mei 2021 ditemukan 14 data konjungsi penyebaban dari kata karena dan lantaran. Berikut beberapa data yang menunjukan konjungsi peyebaban. 


\begin{abstract}
"Tetap menjalankan Prokes 5M secara ketat dan disiplin karena cara terbaik memutus mata rantai Penyebaran Covid-19 ini dengan menegakkan Prokes 5M dalam setiap aktifitas." (D7/3/Mei/21)

"Sehingga total pada hari pertama penyekatan 23.573 kendaraan yang diputarbalikkan lantaran diduga ingin melakukan perjalanan mudik," kata Argo. (D36/7/Mei/21)
\end{abstract}

Kata karena pada data (7) merupakan konjungsi penyebaban yang menghubungkan antarklausa dengan menyatakan sebab tetap menjalankan Prokes $5 \mathrm{M}$ secara ketat dan disiplin pada klausa pertama. Kata lantaran pada data (36) merupakan konjungsi penyebaban yang menghubungkan antarklausa dengan menyatakan sebab 23.573 kendaraan diputarbalikkan pada klausa utama.

b) Konjungsi Persyaratan

Pada rubrik nusantara surat kabar digital Mediaindonesia.com edisi Mei 2021 ditemukan 2 data konjungsi persyaratan dari kata jika. Berikut salah satu data yang menunjukan konjungsi persyaratan.

Pihaknya juga akan membangun posko terpadu untuk pengawasan ikka ada ASN yang masih berani mudik, baik sebelum lebaran maupun setelah perayaan hari raya. (D32/6/Mei/21)

Kata jika pada (32) merupakan konjungsi persyaratan yang menghubungkan antarklausa dengan menyatakan syarat membangun posko terpadu untuk pengawasan pada klausa utama.

c) Konjungsi Tujuan

Pada rubrik nusantara surat kabar digital Mediaindonesia.com edisi Mei 2021 ditemukan 23 data konjungsi tujuan dari kata untuk, agar, dan guna. Berikut beberapa data yang menunjukan konjungsi tujuan.

la mengatakan penurunan tidak hanya pengendara yang mengarah ke Jawa saja, ke Pulau Sumatera, sebanyak 12.044 kendaraan tercatat keluar dari gerbang Tol Cikupa yang mengarah ke Merak untuk menyeberang ke Sumatera. (D41/7/Mei/21)

Atas kejadian tersebut, pihaknya akan mengantisipasi lebih lanjut agar tak terulang lagi dengan menggeser posko penyekatan di Tanjung Pura. (D54/9/Mei/21)

Larangan mudik dari Pemerintah Pusat maupun Daerah tahun ini diberlakukan guna memitigasi angka penyebaran Covid-19 yang tinggi di Indonesia. (D78/12/Mei/21)

Kata untuk pada data (41) merupakan konjungsi tujuan yang menghubungkan antarklausa dengan menyatakan tujuan sebanyak 12.044 keluar dari gerbang Tol Cikupa mengarah ke Merak pada klausa pertama. Kata agar pada data (54) merupakan konjungsi tujuan yang menghubungkan antarklausa dengan menyatakan tujuan mengantisipasi lebih lanjut pada klausa pertama. Kata guna pada data (78) merupakan konjungsi tujuan yang menghubungkan antarklausa dengan menyatakan tujuan larangan mudik dari Pemerintah Pusat dan Pemerintah Daerah yang diberlakukan pada klausa pertama. 


\section{d) Konjungsi Kesewaktuan}

Pada rubrik nusantara surat kabar digital Mediaindonesia.com edisi Mei 2021 ditemukan 7 data konjungsi kesewaktuan dari kata sejak, sebelum, setelah, dan ketika. Berikut beberapa data yang menunjukan konjungsi kesewaktuan.

\footnotetext{
"Pemerintah Kota Tebing Tinggi melalui Satgas Covid-19 secara resmi menerbitkan Surat Edaran yang meniadakan perjalanan mudik bagi seluruh warga dan masyarakat sejak 06 Mei-17 Mei 2021." (D3/3/Mei/21)

Pihaknya juga akan membangun posko terpadu untuk pengawasan jika ada ASN yang masih berani mudik, baik sebelum lebaran maupun setelah perayaan hari raya. (D33/6/Mei/21)

Diketahui, video ratusan pemotor menerobos pos penyekatan viral setelah turut dibagikan oleh sejumlah akun di media sosial. (D58/9/Mei/21)

Tapi andaikata nekat dan lolos dari operasi penyekatan, pasti tidak lolos dihadapan satgas jogo tonggo," kata Gibran ketika meninjau operasi Ketupat Candi 2021 di Pospam Faroka, Selasa (11/5). (D66/11/Mei/21)
}

Kata sejak pada data (3) merupakan konjungsi kesewaktuan yang menghubungkan antarklausa dengan menyatakan waktu meniadakan perjalanan mudik bagi seluruh warga dan masyarakat pada klausa utama berawal sejak tanggal 06 Mei-17 Mei 2021 pada klausa bawahan. Kata sebelum pada data (33) merupakan konjungsi kesewaktuan yang menghubungkan antarklausa dengan menyatakan waktu akan membangun posko terpadu untuk pengawasan pada klausa utama sebelum lebaran pada klausa bawahan. Kata setelah pada data (58) merupakan konjungsi kesewaktuan yang menghubungkan antarklausa dengan menyatakan waktu viralnya video ratusan pemotor yang menerobos pos penyekatan pada klausa utama terjadi setelah turut dibagikan oleh sejumlah akun di media sosial pada klausa bawahan. Kata ketika pada data (66) merupakan konjungsi kesewaktuan yang menghubungkan antarklausa dengan menyatakan waktu yang sama antara perkataan Gibran pada klausa utama dengan peninjauan operasi Ketupat Candi 2021 yang dilakukannya pada klausa bawahan.

\section{e) Konjungsi Pengakibatan}

Pada rubrik nusantara surat kabar digital Mediaindonesia.com edisi Mei 2021 ditemukan 2 data konjungsi pengakibatan dari kata sehingga. Berikut salah satu data yang menunjukan konjungsi pengakibatan.

Direktorat Lalu lintas Polda Jateng juga telah melayangkan surat protes ke kantor dinas di Jawa Timur, karena membiarkan bus lolos memasuki Jawa Tengah, sehingga cukup menyulitkan petugas yang ditempatkan di pos perbatasan antara dua provinsi. (D11/5/Mei/21)

Kata sehingga pada data (11) merupakan konjungsi pengakibatan yang menghubungkan antarklausa dengan menyatakan akibat membirakan bus lolos memasuki Jawa Tengah pada klausa utama.

f) Konjungsi Penyebaban

Pada rubrik nusantara surat kabar digital Mediaindonesia.com edisi Mei 2021 ditemukan 1 data konjungsi perbandingan dari kata seperti. Berikut data yang menunjukan konjungsi penyebaban. 


\begin{abstract}
Dedi menjelaskan pengecualian diberikan bagi kendaraan pelayanan distribusi logistik dan pelaku perjalanan dengan kepentingan mendesak atau yang bersifat non-mudik seperti bekerja/perjalanan dinas, kunjungan keluarga sakit, kunjungan duka anggota keluarga meninggal, ibu hamil dan kepentingan persalinan. (D5/3/Mei/21)
\end{abstract}

Kata seperti pada data (5) merupakan konjungsi perbandingan yang menghubungkan antarklausa dengan menyatakan bahwa pelaku perjalanan dengan kepentingan mendesak atau yang bersifat non-mudik pada klausa utama sama seperti bekerja/perjalanan dinas, kunjungan keluarga sakit, dan sebagainya pada klausa bawahan.

Berdasarkan hasil penelitian ragam jenis konjungsi pada rubrik nusantara surat kabar digital Mediaindonesia.com edisi Mei 2021 menunjukan bahwa pada umumnya ragam jenis konjungsi digunakan untuk menghubungkan informasi dalam berita supaya informasi dalam berita pada rubrik nusantara surat kabar digital Mediaindonesia.com edisi Mei 2021 dapat terhubung. Berdasarkan hasil penelitian ragam jenis konjungsi pada rubrik nusantara surat kabar digital Mediaindonesia.com edisi Mei 2021, konjungsi yang paling banyak ditemukan, yaitu konjungsi tujuan yang ditemukan 23 data. Konjungsi tujuan banyak ditemukan pada rubrik nusantara surat kabar digital Mediaindonesia.com edisi Mei 2021 karena pada rubrik nusantara surat kabar digital Mediaindonesia.com edisi Mei 2021 banyak berita dengan informasi terkait tindakan larangan dan penyekatan mudik beserta tujuan dilakukannya tindakan tersebut. Dengan demikian, konjungsi tujuan banyak digunakan untuk menghubungkan informasi terkait tindakan larangan dan penyekatan mudik dengan tujuan dilakukannya tindakan tersebut.

Hasil penelitian ragam jenis konjungsi penulis memiliki perbedaan dengan beberapa hasil penelitian ragam jenis konjungsi yang pernah dilakukan sebelumnya. Pertama, hasil penelitian penulis berbeda dengan hasil penelitian ragam jenis konjungsi yang pernah dilakukan oleh Ratnaningsih, dkk (2021) karena Ratnaningsih, dkk meneliti ragam jenis konjungsi, seperti konjungsi koordinatif, konjungsi subordinatif, konjungsi korelatif, dan konjungsi antarkalimat, sedangkan penulis fokus meneliti ragam jenis konjungsi, seperti konjungsi koordinatif dan konjungsi subordinatif. Kedua, hasil penelitian penulis berbeda dengan hasil penelitian ragam jenis konjungsi yang pernah dilakukan oleh Rekso, dkk. (2021). Rekso, dkk meneliti ragam jenis konjungsi, seperti konjungsi koordinatif, konjungsi subordinatif, konjungsi adservatif, konjungsi kausal, konjungsi korelatif, dan konjungsi temporal, sedangkan penulis fokus meneliti ragam jenis konjungsi, seperti konjungsi koordinatif dan konjungsi subordinatif.

Ketiga, hasil penelitian penulis berbeda dengan hasil penelitian ragam jenis konjungsi yang pernah dilakukan oleh Sari, dkk. (2020) karena Sari dkk. meneliti ragam jenis konjungsi, fungsi konjungsi, dan makna konjungsi. Hal ini tentu berbeda dengan penulis yang fokus meneliti ragam jenis konjungsi. Keempat, hasil penelitian penulis berbeda dengan hasil penelitian ragam jenis konjungsi yang pernah dilakukan oleh Tara \& WM (2020). Tara dan WM meneliti ragam jenis konjungsi, seperti konjungsi koordinatif saja, sedangkan penulis fokus meneliti ragam jenis konjungsi, seperti konjungsi koordinatif dan konjungsi subordinatif.

Kelima, hasil penelitian penulis berbeda dengan hasil penelitian ragam jenis konjungsi yang pernah dilakukan oleh Melia (2018). Melia meneliti ragam jenis

Silampari Bisa: Jurnal Penelitian Pendidikan Bahasa Indonesia, Daerah, dan Asing Vol. 4, No. 2, 2021 
konjungsi, seperti konjungsi koordinatif, konjungsi subordinatif, konjungsi korelatif, dan konjungsi antarkalimat, sedangkan penulis fokus meneliti ragam jenis konjungsi, seperti konjungsi koordinatif dan konjungsi subordinatif. Setelah memaparkan perbedaan antara hasil penelitian ragam jenis konjungsi penulis dengan beberapa hasil penelitian ragam jenis konjungsi yang pernah dilakukan sebelumnya. Penulis akan memaparkan persamaan antara hasil penelitian ragam jenis konjungsi penulis dengan beberapa hasil penelitian ragam jenis konjungsi yang pernah dilakukan sebelumnya.

Pertama, hasil penelitian penulis memiliki persamaan dengan hasil penelitian ragam jenis konjungsi yang pernah dilakukan oleh Siagian, dkk. (2020) karena Siagian, dkk. meneliti ragam jenis konjungsi, seperti konjungsi koordinatif dan konjungsi subordinatif. Hal ini tentu sama dengan penulis yang fokus meneliti ragam jenis konjungsi, seperti konjungsi koordinatif dan konjungsi subordinatif. Kedua, hasil penelitian penulis memiliki persamaan dengan hasil penelitian ragam jenis konjungsi yang pernah dilakukan oleh Cenderamata (2018) karena Cenderamata meneliti ragam jenis konjungsi, seperti konjungsi koordinatif dan konjungsi subordinatif. Hal ini tentu sama dengan penulis yang fokus meneliti ragam jenis konjungsi, seperti konjungsi koordinatif dan konjungsi subordinatif.

Ketiga, hasil penelitian penulis memiliki persamaan dengan hasil penelitian ragam jenis konjungsi yang pernah dilakukan oleh Jufri (2018) karena Jufri meneliti ragam jenis konjungsi, seperti konjungsi koordinatif dan konjungsi subordinatif. Hal ini tentu sama dengan penulis yang fokus meneliti ragam jenis konjungsi, seperti konjungsi koordinatif dan konjungsi subordinatif.

b. Pemanfaatan Ragam Jenis Konjungsi pada Rubrik Nusantara Surat Kabar Digital Mediaindoensia.com Edisi Mei 2021 sebagai Bahan Ajar Teks Berita di Kelas VIII SMP

Hasil penelitian ragam jenis konjungsi pada rubrik nusantara surat kabar digital Mediaindonesia.com edisi Mei 2021 dapat dimanfaatkan sebagai bahan ajar teks berita di kelas VIII SMP. Maka dari itu, hasil penelitian ragam jenis konjungsi pada rubrik nusantara surat kabar digital Mediaindonesia.com edisi Mei 2021 selanjutnya dimanfaatkan sebagai bahan ajar teks berita di kelas VIII SMP. Pemanfaatan hasil penelitian ragam jenis konjungsi pada rubrik nusantara surat kabar digital Mediaindonesia.com edisi Mei 2021 sebagai bahan ajar teks berita di kelas VIII SMP tentunya disesuaikan terlebih dahulu dengan kompetensi dasar yang ada di dalam silabus mata pelajaran bahasa Indonesia kurikulum 2013 kelas VIII SMP. Pemanfaatan hasil penelitian ragam jenis konjungsi pada rubrik nusantara surat kabar digital Mediaindonesia.com edisi Mei 2021 sebagai bahan ajar teks berita di kelas VIII SMP dapat memberikan tambahan pengetahuan mengenai ragam jenis konjungsi pada rubrik nusantara surat kabar digital Mediaindonesia.com edisi Mei 2021.

\section{Simpulan dan Saran}

Berdasarkan hasil penelitian pada rubrik nusantara surat kabar digital Mediaindonesia.com edisi Mei 2021 ditemukan 88 data ragam jenis konjungsi yang terdiri dari 39 data konjungsi koordinatif dan 49 data konjungsi subordianatif. Konjungsi koordinatif yang ditemukan 39 data terdiri dari 15 data konjungsi penjumlahan, 7 data konjungsi pemilihan, 2 data konjungsi pertentangan, 1 data 
konjungsi pembetulan, 5 data konjungsi penegasan, 1 data konjungsi pembatasan, 1 data konjungsi pengurutan, 2 data konjungsi penyamaan, 2 data konjungsi penjelasan, dan 3 data konjungsi penyimpulan. Konjungsi subordinatif yang ditemukan 49 data terdiri dari 14 data konjungsi penyebaban, 2 data konjungsi persyaratan, 23 data konjungsi tujuan, 7 data konjungsi kesewaktuan, 2 data konjungsi pengakibatan, dan 1 data konjungsi perbandingan. Dengan demikian, jenis konjungsi pada rubrik nusantara surat kabar digital Mediaindonesia.com edisi Mei 2021, konjungsi yang paling banyak ditemukan, yaitu konjungsi tujuan yang ditemukan sebanyak 23 data.

Konjungsi tujuan banyak ditemukan pada rubrik nusantara surat kabar digital Mediaindonesia.com edisi Mei 2021 karena pada rubrik nusantara surat kabar digital Mediaindonesia.com edisi Mei 2021 banyak berita dengan informasi terkait tindakan larangan dan penyekatan mudik beserta tujuan dilakukannya tindakan tersebut. Dengan demikian, konjungsi tujuan pada rubrik nusantara surat kabar digital Mediaindonesia.com edisi Mei 2021 banyak digunakan untuk menghubungkan informasi terkait tindakan larangan dan penyekatan mudik dengan tujuan dilakukannya tindakan tersebut. Hasil penelitian ragam jenis konjungsi pada rubrik nusantara surat kabar digital Mediaindonesia.com edisi Mei 2021 dapat dimanfaatkan sebagai bahan ajar teks berita di kelas VIII SMP. Maka dari itu, hasil penelitian ragam jenis konjungsi pada rubrik nusantara surat kabar digital Mediaindonesia.com edisi Mei 2021 selanjutnya dimanfaatkan sebagai bahan ajar teks berita di kelas VIII SMP.

\section{Daftar Pustaka}

Alwi, dkk. (2010). Tata Bahasa Baku Bahasa Indonesia. Jakarta: Balai Pustaka.

Cenderamata, R. C. (2018). Penggunaan Konjungsi dalam Surat Kabar Republika Online Edisi Maret-Mei 2018: Suatu Kajian Sintaksis. Suar Bentang, 13 (2), 159-167. https://doi.org/10.26499/surbet.v13i2.85

Chaer, A. (2015). Sintaksis Bahasa Indonesia. Jakarta: Rineka Cipta.

Jufri, A. R. (2018). Analisis Penggunaan Konjungsi Koordinatif dan Subordinatif pada Rubrik Nasional Surat Kabar Harian Fajar Edisi Desember 2017. Seminar Nasional Semitra II PBSI 2017. http://prosiding.upgris.ac.id/index.php/SEMITRA17/SEMITRA2017/paper/vie w/2056

Kridalaksana, H. (2008). Kelas Kata dalam Bahasa Indonesia. Jakarta: Gramedia Pustaka Utama.

Mastel. (2019). Hasil Survey Wabah Hoax Nasional. https://mastel.id/hasil-surveywabah-hoax-nasional-2019/ 
Rian Yoana, Oding Supriadi, Sahlan Mujtaba

Ragam Konjungsi pada Rubrik Nusantara Surat Kabar Digital Mediaindonesia.com Edisi Mei 2021 dan Pemanfaatannya sebagai Bahan Ajar Teks Berita di Kelas VIII SMP

Melia. (2018). Analisis Penggunaan Konjungsi Bahasa Indonesia Pada Editorial Surat Kabar Tribun Pontianak. Jurnal Pendidikan Bahasa, 6 (2), 281-293. https://journal.ikippgriptk.ac.id/index.php/bahasa/article/view/676

Moleong, L. J. (2018). Metode Penelitian Kualitatif. Bandung: Remaja Rosdakarya.

Ratnaningsih, dkk. (2021). Analisis Konjungtor dalam Kolom Editorial Surat Kabar Lampung Post. Jurnal Kata (Bahasa, Sastra, dan Pembelajarannya), 9(1), 1-8. http://jurnal.fkip.unila.ac.id/index.php/BINDO1/article/view/22498

Rekso, dkk. (2021). Ragam Konjungsi dalam Artikel Pendidikan Harian Suara Merdeka dan Relevansinya dengan Pembelajaran Teks Eksposisi. Parafrasa: Jurnal Bahasa, Sastra, dan Pengajaran, 3 (1), 1-8. https://jurnal.unikal.ac.id/index.php/parafrasa/article/view/1398

Rohmadi, dkk. (2010). Morfologi Telaah Morfem dan Kata. Surakarta: Yuma Pustaka.

Sa-Ah, M. A. (2019). Pola Reka Bentuk Surat Kabar Thailand dan Surat Kabar Indonesia. Communicatus: Jurnal IImu Komunikasi, 3(2), 1-24. doi:10.15575/cjik.v3i2.6518

Sari, dkk. (2020). Konjungsi pada Harian Rakyat Bengkulu. Jurnal Ilmiah Korpus, 4 (2), 205-214.

Siagian, dkk. (2020). Analisis Penggunaan Konjungsi dalam Kumpulan Artikel pada Rubrik Politik Hukum Koran Kompas. Jurnal Konfiks, 7 (1), 24-27.

Sugiyono. (2016). Metode Penelitian Pendidikan Pendekatan Kuantitatif, Kualitatif, Dan R\&D. Bandung: Alfabeta.

Tara, F. \& WM, N. A. (2020). Penggunaan Konjungsi Koordinatif dalam Berita Editorial Surat Kabar Tribun Jambi Bulan Januari 2019. Aksara: Jurnal Ilmiah Pendidikan Bahasa dan Sastra Indonesia, 4 (1), 39-47. http://dx.doi.org/10.33087/aksara.v4i1.165 